\title{
Interpretation of Tax and Fee Support Policies for Film Industry Under the New Economic Environment
}

\author{
Dong Chunlong 1 ,a \\ ${ }^{1}$ Shanhai Normal University Tianhua College Shanghai, China \\ aalicedongvj@163.com

\begin{abstract}
In May 2020, the Ministry of Finance and the State Administration of Taxation Announcement No. 25 of 2020 issued the announcement on tax support policies for film and other industries. Positive tax policy will promote the development of film industry. This paper analyzes the role of preferential tax policies in promoting the film industry in the modern management environment, and puts forward some suggestions to promote the development of the film industry.
\end{abstract}

Keywords: the new economic environment, the film industry, tax policy.

\section{INTRODUCTION}

Since January 23, Wuhan has been closed down, and the people of the whole country have begun to prepare for the epidemic. In this epidemic, the film industry has been greatly impacted, and the high box office Spring Festival shows almost zero revenue in this epidemic. Under this influence, the recovery of cinema has become slow, even after the end of the epidemic, it will take a long time to buffer! In 2019, the total output of China's culture and art industry will be about 280 billion yuan (including literary and artistic creation and performance, art performance, etc.); The total revenue of the entertainment industry is estimated to be about 458 billion yuan (including indoor entertainment activities, amusement parks, leisure and sightseeing activities, cultural and sports entertainment activities and brokerage services, etc.), of which the operating revenue of the offline entertainment industry, such as song and dance halls, video game halls, Internet cafes, amusement parks, leisure and sightseeing activities and evening activities, is about $170-200$ billion yuan; The box office revenue of the film was 64.266 billion yuan (including 5.859 billion yuan for the Spring Festival, accounting for $9 \%$ of the whole year). Affected by the epidemic, people have reduced their outdoor activities, cultural arts, cinemas, scenic spots, theme parks, KTV, Internet cafes and other entertainment places have been suspended, and large-scale activities such as amusement parks and temple fairs have also been cancelled. It is estimated that the total income of these three sports and entertainment industries alone will drop by at least $10 \%$, accounting for 80.2 billion yuan.

In order to support the development of film and other industries, the Ministry of Finance and the State Administration of Taxation Announcement No. 25 of 2020 issued an announcement on the tax support policies for film and other industries on May 13, 2020. The scope covers value-added tax, enterprise income tax, cultural construction fees, etc. This paper interprets the support of the preferential policies for the development of the film industry from the perspective of the value-added tax and enterprise income tax.

\section{VALUE ADDED TAX}

Radio, film and television services belong to the current value-added tax sales services of modern services, including radio, film and television programs (works) production services, distribution services and broadcast (including projection) services. The tax rate of general VAT taxpayers is $6 \%$, and that of small-scale VAT taxpayers is $3 \%$.

If a general taxpayer has a specific taxable sales behavior stipulated by the Ministry of Finance and the State Administration of Taxation, he may choose to apply the simple tax calculation method, but the input tax shall not be deducted. This includes film screening services.

Announcement No. 25, 2020 of the Ministry of Finance and the State Administration of taxation is as follows: 
From January 1, 2020 to December 31, 2020, taxpayers' income from providing film screening services shall be exempted from value-added tax.

The term "film projection service" as mentioned in this announcement refers to the film audio-visual service provided by the units holding the "film projection business license" to the audience by using the professional cinema projection equipment.

[case 1] a cinema in Shanghai is a general taxpayer mainly engaged in film projection services. It chooses to apply the simple tax method to calculate the tax. In January 2020, it will provide film projection services with a tax free income of 800000 yuan and pay a vat of 24000 yuan. After the resumption of opening up in July, the film screening received 500000 yuan excluding tax. Under the VAT exemption policy, how does the cinema calculate tax?

Analysis: according to the Announcement No. 25, 2020 of the Ministry of Finance and the State Administration of Taxation, before the date of the announcement, the tax that has been collected and should be exempted according to the provisions of this announcement can be offset against the tax that should be paid by the taxpayer and the payer in the following months or refunded ${ }^{[1]}$.

We use the following formula to calculate:

Output VAT $=$ sales revenue $\times 3 \%$

The calculation results are shown in the table below:

Table 1. Value added tax

\begin{tabular}{|c|c|c|c|}
\hline Time & $\begin{array}{c}\text { Film } \\
\text { screening } \\
\text { revenue }\end{array}$ & VAT & Remarks \\
\hline $\begin{array}{c}\text { January } \\
2020\end{array}$ & 800000 & $\begin{array}{c}24000 \\
(800000 \times 3 \%)\end{array}$ & $\begin{array}{c}\text { You can apply for tax refund } \\
\text { or deduct the taxes that } \\
\text { should be paid later }\end{array}$ \\
\hline $\begin{array}{c}\text { July } \\
2020\end{array}$ & 500000 & duty-free & \\
\hline
\end{tabular}

The income from the cinema's film screening service shall be exempted from VAT. Therefore, the 24000 yuan VAT paid in January 2020 can offset the tax payable by the cinema in the following months, and can also submit a tax refund application to the tax authorities.

\section{CORPORATE INCOME TAX}

The Announcement No. 25, 2020 of the Ministry of Finance and the State Administration of Taxation also has corresponding preferential policies for enterprise income tax. The longest carrying forward period of the losses of film industry enterprises in 2020 will be extended from 5 years to 8 years.

Film industry enterprises are limited to film production, distribution and projection enterprises, not including enterprises that spread films through Internet, telecommunication network, radio and television network and other information networks.

The production service of radio, film and television programs (works) refers to the production service of radio, film and television programs and works such as special programs, columns, variety shows, sports, cartoons, radio dramas, TV dramas and films. Specifically, it includes planning, editing, shooting, recording, audio and video text and picture material production, scene layout, post editing, translation (compilation), subtitle production, film title, film ending, flower production, special effects production, film restoration, cataloguing and rights confirmation and other business activities related to radio, film and television programs and works.

The distribution service of radio, film and television programs (works) refers to the business activities of distributing radio, film and television programs (works) to theaters, radio stations, television stations, websites and other units and individuals, and transferring the reporting and broadcasting rights of sports events and other activities by means of sub account, buyout and entrustment.

Broadcasting service of radio, film and television programs (works) refers to the business activities of broadcasting radio, film and television programs (works) in cinemas, theaters, video halls and other places, and broadcasting radio, film and television programs (works) through radio, television stations, satellite communications, Internet, cable TV and other wireless or cable devices ${ }^{[2]}$.

For the losses of qualified film production, distribution and projection enterprises in 2020, the loss carry forward period shall be calculated from 2021, which can be made up with the income from 2021 to 2028 .

[case 2] a cinema in Beijing will have a loss of 20 million yuan in 2020, and there will be no loss before 2020. How to calculate the tax when the enterprise income tax is settled?

Analysis: according to the Announcement No. 25 of the Ministry of Finance and the State Administration of Taxation in 2020, the income of the cinema from 2021 to 2028 can make up the loss of 20 million yuan in 2020 year by year. If the enterprise income tax is settled in 2028 , the loss of 800000 yuan in 2020 is not made up, and the 800000 yuan cannot be made up with the income after 2029.

When making up for the losses of previous years, taxpayers should follow the principle of "making up for the losses due first, and making up for the losses due first".

We use the following formula to calculate: 

tax rate

Enterprise Income Tax $=$ taxable enterprise income $\times$

Table 2. Corporate income tax

\begin{tabular}{|c|c|c|c|}
\hline Time & Taxable income & Corporate income tax & Remarks \\
\hline 2020 & $-20,000,000.00$ & 0 & \multirow{10}{*}{$\begin{array}{c}\text { The income of the cinema from } \\
2021 \text { to } 2028 \text { can make up the } \\
\text { loss of } 20 \text { million yuan in } 2020 \\
\text { year by year. }\end{array}$} \\
\hline 2021 & $5,000,000.00$ & duty-free & \\
\hline 2022 & $1,000,000.00$ & duty-free & \\
\hline 2023 & $1,500,000.00$ & duty-free & \\
\hline 2024 & $1,800,000.00$ & duty-free & \\
\hline 2025 & $1,200,000.00$ & duty-free & \\
\hline 2026 & $1,000,000.00$ & duty-free & \\
\hline 2027 & $2,000,000.00$ & duty-free & \\
\hline 2028 & $1,800,000.00$ & duty-free & \\
\hline 2029 & $2,000,000.00$ & dutiable & \\
\hline
\end{tabular}

[case 3] a cinema in Shanghai has a loss of 20 million yuan in 2020 and a loss of 500000 yuan in 2019. How should the cinema calculate the corporate income tax?

Analysis: according to the principle of "make up for the loss before it matures", the cinema will have a loss of 500000 yuan in 2019, and the income in 2021 should first make up for the loss of 500000 yuan in 2019, and then the income in 2021-2028 will make up for the loss of 20 million yuan in 2020 year by year,

Similarly, if the loss in 2020 has not been made up by the end of the final settlement of enterprise income tax in 2028, it cannot be made up by the income after 2029.

[case 4] a cinema in Shanghai has a loss of 500000 yuan in 2019, 20 million yuan in 2020 and 1 million yuan in 2021 . How should the cinema calculate the tax when the enterprise income tax is settled?

Analysis: according to the principle of "make up for the loss before maturity", the cinema will have a loss of 500000 yuan in 2019, and the income in 2022 should first make up for the loss of 500000 yuan in 2019, and then the income from 2021 to 2028 will make up for the loss of 20 million yuan in 2020 year by year. If the loss in 2020 has been made up in 2023, the income will continue to make up for the loss of 1 million yuan in 2021. If the final settlement of enterprise income tax is completed in 2028, and the loss in 2020 has not been made up, the income after 2029 cannot be used to make up.
If the enterprise has completed the final settlement of the previous year, the quarterly advance payment can make up for the previous year's losses.

\section{CONCLUSION}

At the moment of the epidemic, film companies have been greatly impacted. According to the estimates of a number of media and consulting agencies, the box office revenue in mainland China alone may be reduced by tens of billions of yuan. As for the difficulties faced by film enterprises, various supporting policies have been issued in February. In terms of Finance and taxation, film taxpayers are allowed to postpone declaration, pay taxes, apply for difficulty relief, and deduct relevant taxes according to law. In terms of financial support, it includes tax reduction and fee reduction, deferred repayment, reduced financing costs, delayed insurance payment time and other provisions, which reduce a lot of financial pressure on film companies.

At the same time, the film enterprises should improve their self-help ability, strengthen epidemic prevention measures, formulate emergency plans, and increase publicity, so that the audience can dispel their worries about health and effectively eliminate the sense of panic. 


\section{REFERENCES}

[1] Organized by the Chinese society of certified public accountants. Tax law for guidance materials of the unified national examination for Certified Public Accountants in 2019 [M]. Beijing: China financial and Economic Publishing House, 2019

[2] Textbook com pilation group of national tax professional qualification examination. Tax law I of national tax professional qualification examination in 2019 [M]. Beijing: China tax publishing house, 2019

[3] Textbook compilation group of national tax professional qualification examination. Tax law II of national tax professional qualification examination in 2019 [M]. Beijing: China tax publishing house, 2019

[4] $\mathrm{Xu}$ Zhaoyuan. The impact of the epidemic on China's industry and the priority of response [R], $2020(03.11)$

[5] Xu Ke. Analysis on profit model of film industry [J]. China Civil and commercial, 2020 (5) 